\title{
PENAMBAHAN IKAN PADA PEMBUATAN DENDENG BERBASIS DAUN KATUK (DENKALAR)
}

\author{
Parlin Dwiyana ${ }^{1}$, Rizqi Putri Rahayu ${ }^{2}$ \\ Prodi D3 Gizi Universitas MH Thamrin Jakarta \\ parlindwiyana@yahoo.com
}

\begin{abstract}
ABSTRAK
Dendeng sapi merupakan salah satu produk awetan daging tradisional yang sangat populer di Indonesia yang banyak dijumpai dipasaran dan cukup digemari masyarakat. Harga daging sapi yang cukup tinggi, lebih kurang Rp. 120.000,00/kg nya dan mengandung kolesterol $14 \mathrm{~g}$ per $100 \mathrm{~g}$ menjadi pemikiran peneliti untuk memodifikasi dengan bahan lain yaitu daun katuk. Pemilihan daun katuk karena tanaman yang kurang pemanfaatannya tetapi memiliki nilai gizi yang cukup baik. Kandungan nilai gizi pada daun katuk adalah serta (1,5g), vitamin C (164 mg dan kalsium pada katuk (233 mg) lebih tinggi dibandingkan dengan bayam, serta Fe sama dengan bayam $(3,5 \mathrm{mg})$. Pengganti protein daging sapi digunakan penambahan daging ikan selar. Ikan selar kuning dipilih karena jenis ikan ekonomis dibandingkan sumber protein hewani yang lain, rasanya enak, kandungan proteinnya yang cukup tinggi sebesar 18,8 gram per $100 \mathrm{~g}$, dan mengandung asam amino essensial nilai biologinya tinggi Berdasarkan penjelasan di atas, peneliti melakukan penelitian membuat dendeng berbasis daun katuk dengan penambahan ikan. Penelitian eksperimental, dilakukan dua tahap yaitupenelitian pendahuluan da penelitian lanjutan/utama. Penelitian menggunakan rancangan acak lengkap (RAL) 3 level dan 2 replikasi. Hasil uji statistik Friedmandengan derajat kepercayaan 5\% didapatkan bahwa ada pengaruh penambahan ikan konsentrasi $60 \%$, 80\% dan $100 \%$ terhadap rasa, aroma, warna, tekstur dan tingkat kesukaan denkalar. Penambahan ikan $80 \%$ adalah denkalar yang paling disukai panelis, memiliki kandungan lemak 2,5 g/100 g lebih rendah dibandingkan dengan dendeng daging sapi dan harga yang ekonomis perporsi denkalar (15 g) Rp. 420,00.
\end{abstract}

Kata Kunci : Dendeng, Daun Katuk, Ikan Selar

\section{PENDAHULUAN}

Dendeng sapi merupakan salah satu produk awetan daging tradisional yang sangat populer di Indonesia yang banyak dijumpai dipasaran. Harga daging sapi yang cukup tinggi lebih kurang Rp. 120.000,00/kg nya dan mengandung kolesterol $14 \mathrm{~g}$ per $100 \mathrm{~g}$ sementara dendeng cukup digemari masyarakat, menjadi pemikiran peneliti untuk memodifikasi dengan bahan lain yaitu daun katuk.

Tanaman katuk merupakan tanaman yang kurang dimanfaatkan secara maksimal. Pemanfaatan tanaman katuk oleh masyarakat, cenderung hanya digunakan sebagai bahan makanan sayuran dan pewarna makanan (Sayekti dkk, 2016). Menurut Tabel Komposisi Pangan Indonesia sebagai sumber gizi, kandungan serat pada daun katuk lebih tinggi (1,5 g) dibandingkan daun bayam (0,7 g). Sayur katuk lebih kaya vitamin C (164 mg) dibandingkan dengan bayam (41 mg), namun berdasarkan kandungan mineralnya $(\mathrm{Fe})$ bayam dan katuk sama $(3,5 \mathrm{mg})$, untuk kalsiumnya pada katuk lebih tinggi (233 mg) dibandingkan dengan bayam (166 mg). Melihat nilai gizi katuk yang lebih tinggi dari bayam, penulis tertarik untuk mengolah daun katuk yang kurang dimanfaatkan menjadi dendeng yang bisa disimpan dalam jangka waktu yang lama. Selain daging, ikan juga biasa dikonsumsi sebagai sumber protein. Ikan dapat diolah menjadi berbagai produk olahan dengan langkah stategis untuk menghasilkan ragam produk olahan hasil perikanan adalah melalui pengembangan produk seperti dendeng ikan (Santoso dkk, 2011). Ikan selar kuning merupakan salah satu jenis ikan ekonomis penting dimana banyak dimanfaatkan sebagai pindang, ikan bakar maupun ikan asin oleh para konsumen maupun nelayan karena rasanya yang enak. Selain itu, ikan selar kuning diperdagangkan dalam keadaan segar (basah) dan dibekukan (Abdullah dkk, 1985 dalam Sharfina dkk, 2014). Ikan selar kuning segar merupakan salah satu sumber protein yang sangat dibutuhkan oleh manusia, kandungan proteinnya tinggi sebesar 18,8 gram, mengandung as am amino essensial, 
nilai biologinya tinggi, dan harganya murah dibandingkan sumber protein lainnya (Adawyah, 2011 dalam Napu dkk, 2015). Berdasarkan uraian diatas, penulis tertarik memodifikasi resep yaitu pembuatan dendeng daun katuk dengan penambahan ikan selar sebagai protein pengganti dendeng daging sapi yang mahal. Tujuan penelitian ini adalah untuk mengetahui pengaruh penambahan ikan pada pembuatan Denkalar dan daya terima nya.

\section{METODE}

Penelitian ini dilaksanakan di Laboratorium Gizi Fakultas Kesehatan Universitas MH. Thamrin Jakarta pada bulan Desember 2016.Penelitian ini merupakan penelitian eksperimen ini dilakukan dua tahap yaitu tahap pertama penelitian pendahuluan dan tahap kedua penelitian utama, menggunakan rancangan acak lengkap (RAL) 3 level dan 2 replikasi.

Pengumpulan data dilakukan melalui uji organoleptik oleh 25 panelis agak terlatih dengan menggunakan formulir uji organoleptik terhadap rasa, warna, aroma, tekstur dan tingkat kesukaan secara keseluruhan. Data diolah dengan menggunakan uji Statistik non parametrik Friedman kemudian dilanjutkan dengan uji pembanding ganda Daniel.

\section{HASIL DAN PEMBAHASAN}

\section{Penelitian Pendahuluan}

Penelitian ini bertujuan untuk mengetahui persen penambahan ikan selar sehingga menghasilkan dendeng daun katuk yang baik.Hasil penelitian pendahuluan dapat dilihat pada tabel 1 .

Tabel 1.

Hasil Penelitian Pendahuluan Denkalar

\begin{tabular}{llll}
\hline \multicolumn{1}{c}{ Kriteria } & \multicolumn{1}{c}{$\mathbf{0 ~ g}$} & \multicolumn{1}{c}{$\mathbf{5 0} \mathbf{g}$} & \multicolumn{1}{c}{$\mathbf{7 5} \mathbf{g}$} \\
\hline Rasa & Rasa ikan tidak nyata & Rasa ikan nyata & Rasa ikan agak nyata \\
\hline Aroma & Aroma amis tidak nyata & Aroma amis tidak nyata & Aroma amis agak nyata \\
\hline Warna & Agak Coklat kehijauan & Coklat Kehijauan & Sangat coklat kehijauan \\
\hline Tekstur & Tidak renyah & Renyah & Renyah \\
\hline $\begin{array}{l}\text { Tingkat } \\
\text { kesukaan }\end{array}$ & Agak suka & Suka & Suka \\
\hline
\end{tabular}

Berdasarkan hasil penelitian pendahuluan maka dapat disimpulkan bahwa dendeng daun katuk dengan penambahan ikan selar $50 \mathrm{~g}$ dan $75 \mathrm{~g}$ hasilnya bisa diterima oleh panelis dari pada dendeng daun katuk tanpa penambahan ikan selar.

\section{Penelitian Utama}

Penelitian utama merupakan lanjutan dari penelitian pendahuluan.Berdasarkan hasil uji pendahuluan, konsentrasi penambahan ikan yang dipakai untuk penelitian lanjutan adalah 60\% (T1), 80\% (T2) dan 100\% (T3). 
Tabel 2.

Nilai Gizi Denkalar yang paling disukai

\begin{tabular}{lcc}
\hline \multirow{2}{*}{ Jenis Zat Gizi } & \multicolumn{2}{c}{ Per 100 g } \\
\cline { 2 - 3 } & Denkalar 80 \% & Dendeng Sapi \\
\hline Kalori $(\mathrm{kkal})$ & 207,7 & 301 \\
\hline Protein $(\mathrm{g})$ & 6,8 & 55 \\
\hline Lemak $(\mathrm{g})$ & 2,5 & 9 \\
\hline Karbohidrat $(\mathrm{g})$ & 42 & 0 \\
\hline Besi $(\mathrm{mg})$ & 7,6 & 5,1 \\
\hline Serat $(\mathrm{g})$ & 24,1 & - \\
\hline Kalsium $(\mathrm{g})$ & 67,1 & 30 \\
\hline Vitamin A (SI) & 15,1 & 0 \\
\hline
\end{tabular}

Hasil uji organoleptik dari 25 panelis terhadap rasa, aroma, warna, tekstur dan tingkat kesukaan, dilakukan uji Friedman kemudian dilanjutkan dengan uji Friedman dan uji pembanding ganda Daniel terhadap denkalar dilihat pada Tabel 3.dengan penjelasan sebagai berikut :

\section{a. Rasa Denkalar}

Berdasarkan uji statistik non parametric Friedman, hampir sebagian besar penulis menyatakan rasa ikan tidak nyata sampai rasa ikan sangat tidak nyatayaitu pada T1 (30\%), T2 (40\%) dan T3 (42\%). Berdasarkan uji Friedman dengan derajat kepercayaan 5\%, $X^{2}$ hitung $(28,82)>X^{2}$ tabel $(11,07)$, maka Ho ditolak Ha diterima, berarti ada pengaruh penambahan ikan terhadap daya terima denkalar terhadap rasa. Kemudian dilanjutkan dengan uji pembanding ganda Daniel didapat bahwa T1-T2, T1-T3, T2-T3 tidakbeda nyata. Dengan demikian dapat disimpulkan bahwa presentase penambahan ikan mempengaruhi rasa denkalar tetapi tidak berbeda nyata. Dengan demikian dapat disimpulkan bahwa penambahan ikan dengan berbagai konsentrasi mempengaruhi terhadap rasa denkalar tetapi karena perbedaan konsentrasi penambahan yang kecil tidak dapat membedakan antar perlakuan. Tidak ada perbedaan terhadap rasa bisa dikarenakan ada nya penambahan bumbu sehingga menimbulkan rasa yang lebih dominan. 
Tabel 3.

Hasil Uji Organoleptik terhadap Rasa, Aroma, Warna, Tekstur dan

Tingkat Kesukaan Denkala

\begin{tabular}{|c|c|c|c|c|c|c|}
\hline \multirow{2}{*}{$\begin{array}{l}\mathbf{T 1} \\
\mathbf{N} \\
\end{array}$} & \multicolumn{2}{|c|}{$\mathbf{T 2}$} & \multicolumn{2}{|c|}{ T3 } & \multirow[b]{2}{*}{$\%$} & \\
\hline & $\%$ & $\mathbf{N}$ & $\%$ & $\mathbf{n}$ & & \\
\hline \multicolumn{7}{|l|}{ Rasa } \\
\hline Rasa ikan sangat tidak nyata & 2 & 4 & 3 & 6 & 5 & 10 \\
\hline Rasa ikan tidak nyata & 13 & 26 & 17 & 34 & 16 & 32 \\
\hline Rasa ikan agak nyata & 21 & 42 & 25 & 50 & 19 & 38 \\
\hline Rasa ikan nya & 11 & 22 & 4 & 8 & 8 & 16 \\
\hline Rasa ikan sangat nyata & 3 & 6 & 1 & 2 & 2 & 4 \\
\hline Total & $\mathbf{5 0}$ & 100 & 50 & 100 & 50 & 100 \\
\hline \multicolumn{7}{|l|}{ Aroma } \\
\hline Aroma amis sangat tidak nyata & 1 & 2 & 4 & 8 & 1 & 2 \\
\hline Aroma amis tidak nyata & 17 & 34 & 20 & 40 & 20 & 40 \\
\hline Aroma amis agak nyata & 18 & 36 & 22 & 44 & 19 & 38 \\
\hline Aroma amis nyata & 9 & 18 & 3 & 6 & 10 & 20 \\
\hline Aroma amis sangat nyata & 5 & 10 & 1 & 2 & - & - \\
\hline Total & $\mathbf{5 0}$ & 100 & 50 & 100 & 50 & 100 \\
\hline \multicolumn{7}{|l|}{ Warna } \\
\hline Sangat coklat kehijauan & 4 & 8 & 3 & 6 & 5 & 10 \\
\hline Coklat kehijauan & 10 & 20 & 16 & 32 & 12 & 24 \\
\hline Agak coklat kehijauan & 13 & 26 & 8 & 16 & 11 & 22 \\
\hline Coklat & 14 & 28 & 16 & 32 & 15 & 30 \\
\hline Sangat coklat & 9 & 18 & 7 & 14 & 7 & 14 \\
\hline Total & $\mathbf{5 0}$ & 100 & 50 & 100 & $\mathbf{5 0}$ & 100 \\
\hline \multicolumn{7}{|l|}{ Tekstur } \\
\hline Sangat renyah & 8 & 16 & 14 & 28 & 7 & 14 \\
\hline Renyah & 21 & 42 & 22 & 44 & 14 & 28 \\
\hline Agak renyah & 13 & 26 & 7 & 14 & 9 & 18 \\
\hline Tidak renyah & 5 & 10 & 6 & 12 & 18 & 36 \\
\hline Keras & 3 & 6 & 1 & 2 & 2 & 4 \\
\hline Total & $\mathbf{5 0}$ & 100 & 50 & 100 & $\mathbf{5 0}$ & 100 \\
\hline \multicolumn{7}{|l|}{ Tingkat Kesukaan } \\
\hline Sangat suka & 1 & 2 & 4 & 8 & 4 & 8 \\
\hline Suka & 14 & 28 & 22 & 44 & 20 & 40 \\
\hline Agak suka & 21 & 42 & 17 & 34 & 17 & 34 \\
\hline Tidak suka & 12 & 24 & 7 & 14 & 9 & 18 \\
\hline Sangat tidak suka & 2 & 4 & - & - & - & - \\
\hline Total & $\mathbf{5 0}$ & 100 & 50 & 100 & $\mathbf{5 0}$ & 100 \\
\hline
\end{tabular}

\section{b. Aroma Denkalar}

Penulis menyatakan aroma amis tidak nyata sampai aroma amis sangat tidak nyata yaitu T1 (36\%), T2 (48\%), T3 (42\%), namun masih ada panelis yang menyatakan dendeng aroma amis nyata sampai aroma amis sangat nyata yaitu T1 (8\%).Berdasarkan uji Friedman dengan derajat kepercayaan 5\% terlihat bahwa $\mathrm{X}^{2}$ hitung $(42,68)>X^{2}$ tabel $(11,07)$, ada pengaruh penambahan ikan terhadap daya terima denkalar terhadap aroma. Hajil uji Daniel dapat disimpulkan bahwa persentase penambahan ikan selar mempengaruhi aroma tetapi tidak berbeda nyata antar perlakuan hal ini disebabkan oleh perbedaan konsentrasi penambahan yang kecil dan ikan selar tidak memiliki aroma amis yang kuat. 


\section{c. Warna Denkalar}

Penulis menilai warna denkalar coklat kehijauan sampai sangat coklat kehijauan pada T2 (38\%) dan T3 (34\%) namun pada T1 ada (18\%) menyatakan warna sangat coklat. Hasil uji Friedman dengan derajat kepercayaan 5\% terlihat bahwa $\mathrm{X}^{2}$ hitung $(32,87)>\mathrm{X}^{2}$ tabel $(11,07)$, berartii ada pengaruh penambahan ikan selar terhadap daya terima denkalar terhadap warna. Berdasarkan uji Daniel didapat T1-T3 tidak beda nyata, sedangkan T1-T2, T2-T3 berbeda nyata. Penambahan ikan selar mulai berpengaruh terhadap warna dendeng pada penambahan di atas $60 \%$. Dengan demikian dapat disimpulkan semakin besar konsentrasi penambahan ikan selar maka semakin banyak reaksi Millard yang terjadi sehingga warna semakin coklat.

\section{d. Tekstur Denkalar}

Penulis menilai tekstur renyah sampai sangat renyah untuk semua perlakuan T1, T2 dan T3. Tetapi pada T3 masih ada (4\%) panelis menilai tekstur denkalar keras. Hasil uji statistik Friedman dengan derajat kepercayaan 5\% didapat $\mathrm{X}^{2}$ hitung $(60,3)>\mathrm{X}^{2}$ (11,07), ada pengaruh penambahan ikan terhadap tekstur denkalar. Uji pembanding Daniel didapatkan hasil ada pengaruh konsentrasi penambahan ikan terhadap tekstur tetapi tidak berbeda nyata antar perlakuan Semua perlakuan menghasilkan tekstur denkalar yang sama yaitu renyah.

\section{e. Tingkat Kesukaan}

Penulis menilai tingkat kesukaan terhadap denkalar adalah suka sampai sangat sukaT2 (52\%) dan T3 ( 48\%). Tetapi masih ada panelisyang menilai sangat tidak suka pada T1 (4\%). Hasil Uji statistic Friedman didapatkan ada pengaruh penambahan ikan terhadap tingkat kesukaan denkalar, $X^{2}$ hitung $(51,6)>X^{2}$ tabel $(11,07)$. Hasil uji pembanding Daniel disimpulkan bahwa tingkat kesukaan tidak beda nyata antar perlakuan. Pada penambahan ikan konsentrasi besar, rasa ikan semakin nyata tetapi warna semakin coklat dan tidak disukai. Sebalik nya penambahan ikan sedikit, rasa kurang tetapi warna nya cukup baik sesuai yang diharapkan peneliti (meyerupai dendeng daging sapi).

Berdasarkan penjelasan hasil uji statistik Friedman dan uji pembanding ganda Daniel, panelis menyukai denkalar dengan penambahan ikan $80 \%$ dari segi rasa, aroma, warna, tekstur dan tingkat kesukaan. Peneliti selanjut nya menganalisis nilai gizi dan harga jual denkalar yang paling disukai.

\section{f. Nilai Gizi Denkalar}

Analisiszat gizi denkalar dihitung menggunakan Tabel Komposisi Pangan Indonesia tahun 2009 dan Tabel Bahan Makanan Penukar. Analisis zat gizi dihitung per 100g bahan mentah. Pada tabel 2 dapat dilihat nilai gizi denkalar yang paling disukai (80\%) yaitu lemak lebih rendah 2,5 g dibandingan dengan dendeng daging sapi 9 g, tinggi karbohidrat 42 g, serat 24,1g, kalsium 67,1g, vitamin A 15,1 SI dan besi (7,6 mg).

\section{g. Analisis Harga Denkalar}

Pada denkalar yang paling disukai $(80 \%)$ dilakukan juga analisis harga dengan menguraikan harga per gram bahan yang digunakan mulai dari daun katuk, ikan selar, dan bumbunya. Dari hasil analisis didapatkan harga untuk denkalar yang paling disukai yaitu pada level $80 \mathrm{~g}$ dengan harga yang ekonomis Rp. 16.758 rupiah/604,2 g (40 bj/porsi (15 g)) dimana harga tersebut lebih murah dari produk dendeng daging yang memiliki harga Rp. 105.868 rupiah/ 713 g (48 bj/porsi (15 g)). Untuk 1 kg denkalar harganya Rp. 28.000 dibanding dengan $1 \mathrm{~kg}$ dendeng sapi harganya Rp. 148.468 serta 1 porsi denkalar (15 g) harganya Rp. 420 rupiah/porsi dan harga 1 porsi dendeng sapi (15 g) harganya Rp. 2.227 rupiah/porsi. 


\section{KESIMPULAN DAN SARAN}

Berdasarkan hasil uji organoleptik serta hasil analisa pada pembuatan dendeng daun katuk dengan penambahan ikan selar (denkalar), maka disimpulkan sebagai berikut : Ada pengaruh penambahan ikan terhadap daya terima denkalar (dendeng daun katuk ikan selar) terhadap aroma, warna, tekstur dan tingkat kesukaan, tetapi tidak beda nyata antar perlakuan; Denkalar yang paling disukai dengan penambahan ikan selar $80 \%$; Rendemen denkalar yang paling disukai yaitu dengan penambahan $80 \mathrm{~g}$ dengan hasil rendemen denkalar 98\%; Nilai gizi denkalar lemak (2,5g), kalsium $(67,1 \mathrm{~g})$ dan vitamin A $(15,1 \mathrm{SI})$; Harga denkalar yang paling disukai yaitu pada level $80 \mathrm{~g}$ dengan harga yang ekonomis dengan perbandingan harga 1 porsi denkalar $(15 \mathrm{~g})$ harganya Rp. 420 rupiah/porsi dan harga 1 porsi dendeng sapi (15 g) harganya Rp. 2.227 rupiah/porsi. Harga ini diasumsikan belum termasuk biaya bahan bakar. Saran yang Dapat dilakukan penelitian lebih lanjut terhadap daya simpan denkalar pada suhu beku; Produk denkalar dapat dijadikan sebagai alternatif sumber protein yang ekonomis; Penelitian berbasis daun katuk ini dapat dilanjutkan dengan membuat produk lain seperti keripik, cookies, dan lain-lain.

\section{DAFTAR PUSTAKA}

1. Agustin, W. (2012). "Pengaruh Perendaman Terhadap Kualitas Dendeng Ikan Lele” Jurusan Teknologi Jasa dan Produksi, fakultas Teknik, Universitas Negeri Semarang, Indonesia FSCE 1(1) (2012) Food Science dan Culinary Education Journal.

2. Husna dkk, (2014).Dendeng Ikan Leubiem (Canthidermis masculatus) Dengan Variasi Metode Pemubuatan, Jenis Gula, dan Metode Pengeringan. Vol 6, No.3

3. Mentari, Nona Lia dkk (2016).Potensi Pemberian Ekatrak Daun Sirih (Piper betle L) Sebagai Pengawet Alami Ikan Selar (Selaroides leptolesis). Jurnal Ilmiah Pendidikan Biologi. Vol 1(1-9).

4. Mutiara, (2014).IbM Biskuit Daun Katuk Pelancar Asi. Vol 20, No 77.

5. Napu, Nurhayati dkk (2015).Efektiffitas Jeruk Nipis Dalam Menurunkan Bakteri Escherichia Coli Pada Ikan Selar Kuning (Selaroides leptolepis) Di Pasar Sentral Kota Gorontalo. Jurnal. Vol 3,No.1.

6. Persatuan Ahli Gizi Indonesia (2009). Tabel Komposisi Pangan Indonesia. Jakarta: Kompas Gramedia.

7. Rulianti, Cici . (2009). Pengaruh Penambahan Tapioka dan Suhu Pengeringan Terutama Karakteristik Dendeng Belut (Monoterus albus) Giling, Tugas Akhir Program Sarjana, Jurusan Teknologi PanganUNPAS, Bandung

8. Sa'roni dkk, (2004). Effectiveness Of the Sauropus androgynus L. Mer. Leaf extracts in increasing mother's breast milk production. Media Litbang Kes.14 : 20-24.

9. Selvi dkk, (2012).Phytochemical analysis and GC.MS Profiling In The Leaf Of Sauropus androgynus L.Mer. Int J Drug Dev Res, 4 : 162-167.

10. Santoso dkk, ( 2011). Peningkatan nilai tambah ikan dan limbah olahannya melalui teknologi perorangan dan pengolahan, Dierktorat pengolahan hasil ditjen pengolahan dan pemasaran hasil Perikanan Kementrian Kelautan dan Perikanan, Jakarta.

11. Sharfina, Maizan dkk (2014).Potensi Lestari Ikan Selar Kuning (Selaroides leptolepis) Di Perairan Selat Sunda.Jurnal Mariene Fisheries. Vol 5,No.1 (101-108). 
12. Utari, Pranata dkk, (2017). Pengaruh Perbandingan Jamur Tiram (Pleurotus ostreanus) Dengan Jamur Kuping (Auriculturia polytricha L.) Terhadap Karakteristik Dendeng Nabati.

13. Qotimah dkk, (2014).Pengaruh Level dan Suplementasi Ekstrak Daun Katuk (Sauropus andogynus) Terhadap Kualitas Karkas Broiler.Jurnal Sain Peternakan Indonesia. Vol 9,No.2.

14. [BSNI].Badan Standarisasi Nasional Indonesia. 1995. SNI 01-2908-1992 Tentang Syarat Mutu Dendeng Ikan. Standar Nasional Indonesia. Jakarta.

15. Waluyo, Inggrid Vina (2010). Pengaruh kombinasi jenis sakarida terhadap sifat fisik kimiawi dan Organoleptik dendeng babi giling. 